\title{
THE LIBER URICRISIARUM IN WELLCONE MS 225 AND THE ADAPTATION OF SOURCE TO AUDIENCE'
}

The tradition of vernacular medical texts in medieval England, a period extending approximately from the year 600 to the end of the 15th century, demonstrates in some of its earliest examples the practice characteristic of many vernacular texts throughout the Middle Ages of transmitting the knowledge of established medical authorities to a lay audience. The first of these, the Leech books of Bald ${ }^{2}$ (collections of remedies and charms believed to have been written during the first half of the 10 th century and so named because of the Anglo-Saxon medical practitioner who owned them), are the earliest extant medical texts in English that transmit, via Latin translations, medical knowledge from ancient Greek authorities, according to Charles Talbot ${ }^{3}$. Likewise, the Anglo-Saxon Herbal (produced around the year 1000 , complete with illustrations) makes available in English the Herbarium of the pseudo-Apuleis and contains material from Dioscorides. ${ }^{4}$ Though such examples are admittedly sparse (as is the case with Old English medical literature overall), they not only demonstrate the existence of a vernacular tradition in England from the 10 th century onward but also represent a reliance on learned sources in establishing that tradition. 5

When the number of vernacular texts in England increased dramatically in the later Middle Ages, specifically in the late 14th and early 15th centuries, so did their reliance on learned medical literature in Latin for their content. (This feature in fact characterizes vernacular medical texts in western Europe overall, as Gerhard Baader and Gundolf Keil have indicated.) ${ }^{6}$ Many of these texts take the form of translations or adaptations of authoritative medical texts from Latin into Middle English ${ }^{7}$ and show evidence, among other things, of the reception of Arabic learning in medieval England. Yet this fact, that vernacular medical literature is based principally on Latin texts whose knowledge it disseminates to a broad audience, does not mean that such texts simply repeat word for word the information in their Latin sources. The different audience for vernacular literature, expanded to include the literate lay 
practitioner as well as the academically trained physician, influenced both the form and the content of the resulting texts: typically, the practical needs of the lay members of the audience take precedence over theoretical concerns. ${ }^{8}$ Consequently, the translator or compiler revises, edits, and adapts his sources, even when he may announce to the audience that he has translated his source virtually word for word into the vernacular. ${ }^{9}$,

Such a declaration appears in Welcome MS 225 (hereafter, MS 225), in the Middle English treatise on uroscopy occupying the bulk of the manuscript and entitled Liber Uricrisiarum (literally, "the book of the decisions of urine"). ${ }^{10}$ Yet an assertion on the part of the compiler appearing near the end of the treatise, that he has rendered the De Urinis by Isaac Judaeus "nerhand word for worde" into English, ${ }^{11}$ misrepresents what the compiler has in fact done with his principal Latin source. ${ }^{12}$ The relative brevity of the De Urinis, when compared with the sheer length of the Middle English Liber Uricrisiarum, suggests that the compiler of the Middle English text offers his reading audience an elaboration rather than a literal translation of the original Latin text. ${ }^{13}$ In many instances, the compiler seems to have both expanded and condensed the material in his main source, adding explanation to provide context for a point presumably unfamiliar to his audience, or deleting information he apparently considered less relevant to the pragmatic concerns of lay practitioners. The overriding principle governing the compiler's treatment of his source material in MS 225 is his attention to the lay members of his audience, his desire to communicate learned medical knowledge as clearly to them as possible. ${ }^{14} \mathrm{~A}$ comparison of the resulting Middle English treatise with its Latin source implies that the compiler may have envisioned a lay audience relying principally on knowledge gained through experience and the reading of vernacular texts in its practice of uroscopy, since it lacked the formal education in medicine that a course of study at university would have provided. Indeed, the compiler's own statement of rhetorical purpose appearing in MS 225 shows that he had precisely this audience in mind: "And all I wald undo in common speech, pat all men might understand \& know, 3yf only man wald fund me my sustenance" (p.142).

This statement specifying both rhetorical purpose and audience (as well as the compiler's own financial predicament) other is one key factor distinguishing the Liber Uricrisiarum in MS 225 from other uroscopies in Middle English. ${ }^{15}$ In addition, MS 225 presents a complete text of the Liber Uricrisiarum; it does not lack portions of the treatise as do other 
Middle English versions. ${ }^{16}$ As a uroscopic text it cannot be classified according to origin exclusively with popular medical literature (e.g., some recipe books) on the one hand or with university texts on the other, but more accurately represents the middle ground between these "poles of a continuum", as Linda Voigts and Michael R. McVaugh have suggested concerning uroscopic texts in general. ${ }^{17}$ In using the De Urinis of Isaac Judaeus as his main source and citing Isaac frequently throughout, the compiler of the Liber Uricrisiarum clearly draws on academic medical literature, yet the resulting Middle English text shows his efforts to adapt his source to the uneducated members of his audience.

Selected corresponding passages from the Latin and Middle English versions demonstrate that the compiler engages in both minor and major revision of his source, deleting portions of the original text, replacing precisely worded statements with generalizations, and adding explanation of points in the original treatise. This latter feature in particular represents the compiler's emphasis on drawing connections among points and in general providing for his audience a sense of context for the technical knowledge being conveyed. Even the examples of minor editing show generally consistent and purposeful application of the compiler's guidelines for revision that we can infer from the text, as the following passages indicate. In the Latin text, Isaac Judaeus cites a statement by Galen on the kind of urine that signifies the health of an individual, in that the urine has little or no hypostasis (a type of sediment in urine). The statement appears in Chapter One of De Urinis:

... hoc est hypostasis, unde Galienus: "Urina in sanis pauxillam aut nullam habet hypostasim, cum in vase diu remanserit, quod est propter virtutem membrorum expellentium superfluitates ciborum per poros corporum." Hypostasis ergo monstrat quantitatem actionis naturae in tertia digestione in membris existente, monstrat et qualitatem coctionis chimorum in raritate membrorum, qui generativi sunt morborum. ${ }^{18}$

The citation from Galen is followed by a statement by Isaac on the importance of hypo stasis in revealing the proper functioning of the body - both the "quantity" or degree of bodily function in the third digestion and the quality of the "cooking" of the stomach fluids. The corresponding passage in the Middle English treatise, appearing in Book One, Chapter Five, renders the original Latin as follows:

And parefore says Galien pat uryn of pe heyle folk, when it has standyn \& restyd, hyt has bod lytyll ypostasis or ellys nane, \& pis is pe philosophy, id est pis is pe skyll. For pe kynd is myghty in hymself \& cachys owt pe 
superfluiteis be be poris of body. And barefore ever when ypostasis apperys be pe uryne, it tellys how mykyll kynd \& pe humours [are] wyrkynge in pe 3 [rd] digestion. (pp. 64 -65.)

The compiler has indeed translated the citation from Galen literally; the phrases added by him ("pis is pe philosophy, id est pis pe skyll") merely serves the stylistic purpose of highlighting the explanation that follows, as if to ensure that the reader pay more attention to it. Minor revision is evident, though, in the compiler's imprecise translation of Isaac's comment on Galen's statement (respectively, the last sentence in each quoted passage above). The Middle English version has lost some of the specificity of the original Latin - quantity and quality are two separate and distinct entities, yet only the first is retained in the vernacular ("how mykyll"); ${ }^{19}$ furthermore, "humours" and "chimorum" (stomach fluids) are not identical-but the resulting simplifying and generalizing of the original statement shows even on a small scale the compiler's tendency to "uncomplicate" his source material for the lay reader.

The corresponding passages in both treatises describing the urine flask and its proper use show a greater degree of departure from the original text than the previous example, a departure that takes the form not of simplification but of elaboration or expansion of the source. The description of the proper urine flask for collecting and examining urine appears in Chapter Two of De Urinis as follows: "Colligatur in vase vitreo albo, claro, et rotundo in fundo ad vesicae formam et operiatur a frigido aere, ut in calore perduret naturali sicut exit a corpore" (p.15). The Middle English version in Book One, Chapter Eight of the Liber Uricrisiarum retains the precise description of the original even as it leaves out some detail: "Pe place pare pe uryn aw to be collect \& takyn in aw to be a vessell of glas, clen, whyt, \& thyn, \& clere, \& rounde, \& schapyn lyk pe vesye of man" (p.78). Immediately obvious in the Middle English version is the compiler's literal translation of the descriptive adjectives in the Latin, with a few synonyms added for good measure. Also noticeable is the compiler's deletion, due to perhaps nothing more than oversight on his part, of Isaac's instruction to the physician to cover the flask after collecting a urine sample to retain its natural heat. The detail can hardly be considered too theoretical in nature to include; moreover, throughout the section in which this passage appears the compiler stresses the care with which one should collect and examine urine to ensure accurate diagnosis, thus showing that he takes such detail seriously. Particularly striking about the Middle English version, however, are the statements the compiler has added to the description in his Latin source to explain why it 
is appropriate that the urine flask resemble the shape of the human bladder:

For ryght as partys of uryn has pam in pe vesye within man, ryght sa, because of pe forme \& pe fygore of pe vessell, pe uryn may schew hyt haly in hys kynde. For o pis wyse all pe uryn \& all hys partys schewis pam to yloulr syght \& to pe dome of mane in ordor of kynde, or ellys noght. Kynd sa ordanys, schapys, \& disponys on syk wys in pe body \& in all pe membris of pe body, pat amang pe partyes pat are called contenta urine (bodys apperand in pe uryne), as yu sall se in pe 2[nd] buk, whylk are decydit \& departyt fra pe membris of pe body, he dyvysis \& departys pam \& puttys pam in pe uryn as pai are caused \& gendyrd in pe body: the myddys in pe myddys, \& pe overmast abovyn. (pp.78-79)

This explanation, evidently triggered by the reference in Isaac to the bladder like shape of the urine flask, makes clear to the lay reader that features like form are not arbitrary but rather highly relevant. Furthermore, it provides for the medical practitioner a sense of context for and connection among three things: the tools of the trade, namely, the urine flask; the natural shape and disposition of the human body; and the practice of uroscopy. The passage establishes a direct relationship between the location of various types of sediment in the urine sample (collected in the flask) and the location of parts of the body and thus disease, thanks to the correspondence, considered valid by medieval practitioners, between the form of the flask and that of the human bladder. (Thus, sediment suspended near the top of the urine sample indicates the upper region of the body; sediment in the middle of the sample the middle region of the body; and so on.) As the length of the passage indicates, the explanation continues for several lines before the compiler returns to his main source. In general, his elaboration in this section of one key detail in his source exemplifies his practice throughout the treatise of providing explanation and context for the instructions and information he transmits to his audience, evidently taking little knowledge, if any, for granted on the part of his readers. Moreover, his view of uroscopy as a coherent, unified science is as apparent here as his practice of adapting source material to his audience.

The compiler of the Liber Uricrisiarum applies the same technique of expanding his source by including explanation not present in the original as effectively to a discussion of a fundamental principle of medieval physiology, i.e., compleccion, as he has to the specifications for the urine flask. Implicit in the original passage in Isaac's De Urinis is the assumption that the reader is already aware of the relationship among the 
four elements (air, fire, water, and earth), the four qualities (heat, cold, moisture, and dryness), and the four humors (blood, choler, phlegm, and black bile) as the basis for understanding the four temperaments (sanguine, choleric, phlegmatic, and melancholic) and their relation to disease. As a result, Isaac instead immediately identifies the finer gradations of complexio as he introduces the topic in Chapter Five:

De diversitate urinae secundum complexionem. Complexio generaliter dividitur in duo, vel enim naturalis est vel non naturalis. Naturalis est ex quattuor composita qualitatibus, altera alteram non superante, hanc homines habentes complexionem urinam in liquore et colore habent temperatam, id est citrinam, claram et mediocrem inter citrinum et igneum colorem, liquorem mediocrem inter grossum et subtilem. Non naturalis principaliter in duo dividitur, vel enim est simplex vel composita. Simplex est, cum una qualitas corporis dominatur complexioni. Qualitates enim sunt quattuor, caliditas, frigiditas, humiditas et siccitas, unde et simplices sunt quattuor complexiones, calidae et frigidae, humidae et siccae. (pp. 21-22)

Isaac does list the four qualities in the context of defining natural and non natural complexio, and then continues (in the text following the passage above) with a discussion of the characteristics of the kind of urine associated with each type. The medieval compiler, however, uses his introduction of compleccion (in Book One, Chapter Nine) first as an opportunity to educate his reader on the relationship among the elements, qualities, humors, and temperaments before discussing in specific terms how such matters affect a patient's urine:

For to knaw what compleccion is, undyrstand pat pare are 4 elementys: ignis, aer, aqua, \& terra / And alsa pare are 4 humors, videlicet sanguis, colera, fleuma, \& malancolya: auctoritate blud, color, fleume, \& malancoly. Now is pare 4 qualiteis awnswerand to pe 4 elementys \& to pe 4 humors, as caliditas, frigiditas, siccitas, \& humiditas: auctoritate hathede, dryhede, caldhede, \& mosthede. Now pis word aunswer-and in pis mater is as mykyll for to say as acordande in kynde. Now pe 4 qualiteis aunswers be pe 4 elementys \& to pe 4 humors. For blud aunswers to aere, colre to fyre, fleume to water, malancoly to erth. For aere \& blude is hat \& moyst; fyre \& colre, hat \& dry; water \& fleume, cald \& moyst; erth \& malancoly, cald \& dry / Pus may yu se how pe second four awnswers to pe fyrst four, \& pe thryd four to bath four. And of pise 3 fours is everythynge erthly compound \& mad, \& opon pe temperature \& disposition of pis 34 ['s] standys pe state, id est hele or unhele, lyf or dede, of man \& best. (pp. $83-84$ ) 
These statements lead to a description of the physical characteristics and personality traits of each temperament, followed by a discussion of the four ages of $\operatorname{man}^{20}$ and a digression on the ages of the world, before the compiler specifies the type of urine representative of each compleccion. In the process of adapting the Latin text, the compiler leaves out of the Middle English version any reference to natural or non natural complexio, instead using as labels the terms for the four qualities, which do appear in Isaac; and the four temperaments (i.e., sanguine, choleric, phlegmatic, and melancholic), which do not. ${ }^{21}$ The generalization (absent in Isaac's treatise) appearing at the end of the Middle English version above plainly and thus effectively summarizes the potentially confusing connection among the various sets of fours in which the lay reader might lose himself. It allows the reader to place the technical detail of the passage in the broad context of health and disease.

One other feature of the Middle English text notable for its absence in Isaac's treatise and thus part of the compiler's elaboration of his main source is a brief comment concerning medieval "bedside manner" appearing in the instructions for examining a patient's urine (Book One, Chapter Eight): "And tak heide pat emang all pis poyntys, if yu be in presence of pe seyk, yu bus pyn hym all comfurth pat yu may \& mast, \& counsellynge hym for hys saule" (p.80). Such advice, addressed directly to the reader, reveals the compiler's recognition of the everyday world of medical practice that his audience no doubt encountered, educated practitioners or not; it is a simple reminder that the practitioner view his patient as a human and spiritual being even as he concentrates on the contents of the urine flask. By contrast, it makes Isaac's De Urinis seem much more the academic text in its tone and general approach to the subject of uroscopy. Here and in other instances the Liber Uricrisiarum appears patient-oriented rather than disease-oriented.

Such techniques of revision in working with sources may have their drawbacks; one may, for example, be obliged to admit that the medieval compiler sacrifices stylistic control in his efforts to tailor his source to the lay members of his audience. Compared to the Middle English text, the Latin of Isaac's treatise reads stylistically as a concise, coherent whole. Yet the compiler's clear sense of rhetorical purpose throughout the vernacular treatise, governing his treatment of his principal source, provides coherence of another sort where stylistic unity may be lacking. Any critique one may justifiably raise concerning matters of style in the Liber Uricrisiarum diminishes neither the importance of the treaties as a text addressing lay medical practitioners nor the compiler's accomplishment in making available to them authoritative medical knowledge. ${ }^{22}$ 


\section{NOTES}

1 This article, printed here in revised form, was originally presented to the Medieval Association of the Pacific under the title, "The Adaptation of Source to Audience in Middle English Medical Prose: The Example of Wellcome MS 225," at the University of California, Irvine, on February 21, 1992 .

2 See the text of the Leechbooks in the first two volumes of T.O.Cockayne's nineteenth century edition Leechdoms, Wortcunning, and Starcraft of Early England, revised with an introduction by Charles Singer, 3 vols. (London: Holland Press, 1961).

Charles H.Talbot, Medicine in Medieval England (London: Oldbourne Book Co., Ltd., 1967), p.18. Talbot mentions the borrowings in the Leechbooks from Paul of Aegina, a compiler of Galen, and of Alexander of Tralles, the sixth-century Byzantine physician, among others. See also the more recent studies by M.L.Cameron, "Bald's Leechbook: Its Sources and Their Use in Its Compilation<" Anglo-Saxon England 12 (1983), pp. 153-82; and "The Sources of Medical Knowledge in Anglo-Saxon England," Anglo-Saxon England 11 (1983), pp. 135-55.

H.J. de Vriend provides a critical edition of the Old English text with Latin version in The Old English Herbarium and Medicina de Quadripedibus, EETS o.s. 286 (London: Oxford University Press, 1984).

5 These examples exist side by side with other texts, such as charms, that draw on folkloric or magical sources; see the collection of charms in the Lacnunga in J. H.G.Grattan and C.Singer, Anglo-Saxon Magic and Medicine Illustrated Specially from the Semi-Pagan Text "Lacnunga" (Oxford, 1952). Though the Leechbooks also contain some charms, their number is much smaller in proportion to those in the Lacnunga.

6 Gerhard Baader and Gundolf Keil, "Einleitung," in Medizin im mittelalterlichen Abendland, eds. Gerhard Baader and Gundolf Keil (Darmstadt: Wissenschaftliche Buchgesellschaft, 1982), p.26.

7 Middle English is of course the dominant language of such texts, though not the only one; passages in Latin or Anglo-Norman often occur.

8 Baader and Keil, pp. 26-27.

9 See the similar observations of Faye Marie Getz concerning the Middle English version of Gilbertus Anglicus in Healing and Society in Medieval England: A Middle English Translation of the Pharmaceutical Writings of Gilbertus Anglicus, Wisconsin Publications in the History of Science and Medicine, No. 8 (Madison: University of Wisconsin Press, 1991), pp. xlivxlviii: and those of Peter Murray Jones concerning Middle English versions of John of Arderne in "Four Middle English Translations of John of Arderne" in Latin and Vernacular: Studies in LateMedieval Texts and Manuscripts, ed. A. J. Minnis, Proceedings of the 1987 York Manuscript Conference (Cambridge: D. S. Brewer, 1989), p. 61.

${ }^{10}$ Internal evidence places Wellcome MS 225 in the first quarter of the fifteenth century. It is written in a predominantly Northern dialect, although some East Midland forms occur.

${ }^{11}$ Folio $143 \mathrm{v}$ (p. 483 in the edition cited below; the treatise occupies ff. $5 \mathrm{r}-143 \mathrm{v}$ in the manuscript). In the same statement the compiler refers to Isaac's treatise as the "Buk of Uryns" and to Isaac himself as "pe noble Jew." For the complete text of Wellcome MS 225, see Joanne Jasin, "A Critical Edition of the Middle English Liber Uricrisiarum in Wellcome MS 225" (diss., Tulane University, 1983; Ann Arbor, UMI, 1984). All subsequent quotations from the Liber Uricrisiarum in Wellcome MS 225 are taken from this edition of the manuscript and are documented by page number. In the edition, expansion of all abbreviations and suspensions in the manuscript is indicated by underlining. I have followed modern conventions in adding 
punctuation. Alternate readings provided by the compiler appear in parentheses. I completed the dissertation working solely from microfilm; the quotations provided here, however, incorporate revisions based on my subsequent examination in person of the original manuscript at the Wellcome Institute for the History of Medicine in London.

12 The Latin treatise, one of the principal works of the Hebrew physician Isaac Judaeus (born in 830 in Egypt), was originally written in Arabic and became available to the West in the eleventh century, thanks to Constantinus Africanus' Latin translation of the Arabic text. It remained one of the chief authoritative works on the science of uroscopy, the principal method of diagnosis, throughout the Middle Ages, and as part of the Articella was required reading for students in the medical faculties at Salerno, Paris, Bologna, Montpellier, Cambridge, and Oxford.

${ }^{13}$ Moreover, since the compiler of the Liber Uricrisiarum in MS 225 cites numerous other authorities, medical and otherwise, throughout the treatise, it is clear that he has included in the Middle English text material from other sources in addition to De Urinis. The scope of this discussion, however, is limited to the main source cited by the compiler, namely, Isaac's uroscopic text.

14 As one would expect, this governing principle affects the prose style of the Middle English treatise as well, as I have discussed in a forthcoming article entitled "The Compiler's Awareness of Audience in Medieval Medical Prose: The Example of Wellcome MS 225," to be published in the lournal of English and Germanic Philology (tentative date of publication: April, 1994).

15 In his essay "Medical Manuscripts in Middle English" (Speculum 45 [1970], pp. 393-415), Rossell Hope Robbins lists 35 uroscopies in Middle English, several of which are fragments. Linda Voigts updates Robbins' list in her essay "Medical Prose" in Middle English Prose: A Critical guide to Major Authors and Genres, ed. A.S.G.Edwards (New Brunswick: Rutgers University Press, 1984),pp. 315-35. Though the Liber Uricrisiarum in MS 225 closely resembles another Middle English uroscopy, the Henry Daniel treatise in Sloane 1100, in both wording and content, Sloane 1100 does not contain the statement of rhetorical purpose that appears in MS 225 as quoted above. Sloane 1100 may be added to the list of manuscripts containing uroscopies cited by both Robbins, pp. 399 and 414 - 15; and Voigts, pp. 328-29.

16 The manuscript does, however, lack two figures mentioned in the text, one of a wheel used in calculating leap year and the other of the rota celi or rota mundi, presumably depicting the Ptolemaic universe. Wellcome MS 226 also contains a Middle English text entitled Liber Uricrisiarum that does include much of the material of MS 225, but it is incomplete, ending on folio $71 \mathrm{v}$ in Chapter Eight of Book Two, where as MS 225 continues with a third book, ending on folio 143v. See S.A.J.Moorat, Catalogue of Western Manuscripts on Medicine and $\underline{\text { Science }}$ in the Wellcome Historical Medical Library (London: Wellcome Historical Library, 1962), pp. 143-44.

17 Linda E.Voigts and Michael R.McVaugh, A Latin Technical Phlebotomy and Its Middle English Iranslation, Transactions of the American Philosophical Society, 74, Part 2 (Philadelphia, 1984), p.21.

18 Johannes Peine, Die Harnschrift des Isaac Judaeus (Leipzig: Robert Noske, 1919), p. 13. All subsequent quotations from Isaac's De Urinis are taken from this edition and are documented by page number. Peine's edition is based on the text appearing in Opera Omnia Isaaci (Lyon,1515), which he comparer with MS 1154 in the Leipzig University Library to verify the accuracy of the sixteenth-century printed edition. Peine does not however, refer to or include 
in his edition the extensive commentary by Petrus Hispanus, included in the copy of the 1515 edition that I examined in the Staatsbibliothek in Berlin (West).

${ }^{19}$ That this simplification is a result of the inability of Middle English vocabulary to render the distinction is unlikely, since the Middle English equivalents of "quantity" and "quality" occur elsewhere in MS 225.

${ }^{20}$ Also mentioned in Isaac's treatise, p.21 in Peine's edition.

21 This discrepancy naturally suggests, as mentioned previoysly, that the compiler may be combining material from another source with the information in De Urinis.

22 I gratefully acknowledge the assistance of both the Luftbrueckendank Foundation for research funding and the Institute for the History of Medicine of the Free University, Berlin, for research facilities in the preliminary preparation of this article.

\section{Joanne JASSIN}

Departament of English and Comparative Literature

California State University, Fullerton

Fullerton, California 92634-9480

U.S.A. 